elderly. The recent study suggested that the carbohydrate moiety of oral epithelial cells was strict requirement for inhibition of growth of $C$. albicans in vitro. In the present study, to investigate the mechanisms by which oral epidermal cells inhibit the growth of Candida, we examined the effect of hyaluronan (HA), which is one of cell surface carbohydrate moiety, on growth C. albicans.

\title{
4. A local delivery system for cytotoxic agents to tumors by focused sonoporation
}

岩永賢二郎（九歯大·病態制御）

超音波を用いた新しい薬物・遺伝子導入法であるソノポレーション法を癌治療に応用できないか検討した。In vitro および in vivo の実験系で扁平上皮癌細胞に数種類の物質を導入し, 致死活性の発現を調べた。

In vitro の実験系で, 超音波発振装置を用いヒト歯肉扁平上皮癌細胞 Ca9-22 cell B Bleomycin および細胞毒素関 連遺伝子 (pVIVO1-cdtB) を導入し，細胞の状態を観察した。 さらに，同装置を用いて担癌マウスにBleomycin お よび pVIVO1-cdtB を導入し，抗腫瘍効果を検討した。

In vitro および in vivo の実験系で Bleomycin および pVIVO1-cdtBを Ca9-22 cell に導入したところ, 強い致死 活性の発現が認められた。

ソノポレーション法は, これまで報告されてきた導入法より低侵襲であり, 安全で治療効果が高い癌治療法として の可能性が示唆された。

\section{A local delivery system for cytotoxic agents to tumors by focused sonoporation}

Kenjiro Iwanaga (Division of Maxillofacial Diagnostic and Surgical Science, Kyushu Dental College)

Recently, a new potent nonviral gene transfer method known as 'sonoporation' has been developed. We used sonoporation to deliver bleomycin or transfect a cdtB-expressing plasmid into human gingival squamous carcinoma cell line, $\mathrm{Ca}$-22, and examined cell viability in vitro and in vivo. We found that the administration of bleomycin or cdtB-expressing plasmid followed by sonoporation induced marked growth inhibition of Ca9-22 cells, and apoptotic cells were also observed in vitro and in vivo. These findings suggest that local administration of cytotoxic agents with sonoporation is a useful method for molecular cancer therapy. 